\title{
Service Export Sensitivity to Internet Adoption: Evidence From Dynamic Panel Data Analysis
}

\author{
Walid Chatti ${ }^{1} \&$ Haitham Khoj ${ }^{1}$ \\ ${ }^{1}$ Faculty of Economics and Administration, King Abdulaziz University, Jeddah, KSA \\ Correspondence: Walid Chatti, Assistant Professor, Faculty of Economics and Administration, King Abdulaziz \\ University, Jeddah, KSA. Tel: 966-56-406-8081.
}

Received: September 14, 2020

Accepted: November 17, 2020

Online Published: December 20, 2020

doi:10.5430/rwe.v11n6p259

URL: https://doi.org/10.5430/rwe.v11n6p259

\begin{abstract}
This study aims to examine the causal linkages relating service exports to internet penetration for 116 countries over the period 2000-2017. Taking into account a wide panel of countries, we apply 2-Step GMM methodology for dynamic panel data models. The results show a bi-directional causality relating service exports to internet adoption for developed countries. For the global panel and developing countries, we find those same results attest a positive relationship between the internet adoption and service exports, but in the opposite way; the impact is very low and not significant. Regarding developing countries, despite the fact that internet positively affects service exports, it is considered less efficient than in developed countries.
\end{abstract}

Keywords: internet penetration, service exports, simultaneous equations, GMM

\section{Introduction}

Efficient internet access is considered crucial for delivering information services, requiring optimum quality national ICT infrastructure (World Bank, 2016). There is no doubt that internet access enables businesses, governments, and households to profit from specialized services (e.g. insurance, finance, travel, calling centers, application development, consulting services, and engineering activities). ICT enables companies to minimize transaction costs (Markusen, 1989; Markusen and Strand, 2008), and thus to increase total productivity (Fink et al. 2005; Tang, 2006; Chatti, 2020). In addition, it can promote the use of knowledge-intensive services, thereby facilitating technology transfer across regions and countries, particularly from developed to developing countries (e.g. via FDI) (Maurseth and Verspagen, 1999; Riou, 2003; Chatti et al. 2019). ICT provides new service export opportunities for developing countries (OECD, 2008; World Bank, 2016), especially for those traditionally limited by high transportation costs. Overall, the most important advantage of ICT is being able to export specialized services without the use of traditional modes of transport (Freund and Weinhold, 2002; Grossman and Rossi-Hansberg, 2008).

Despite the importance of internet use for international service trade, few studies have attempted to examine the causal relationship between service exports and internet adoption. This study is the first undertake a comparative analysis of factors that affect trade in services in developing and developed countries (e.g. employment in service and industry). The principal contributions of this study are twofold: from a theoretical point of view, this research underlines the key role that can be played by internet technology to enable access to new service export opportunities for corresponding economies, and from an empirical point of view, this study aims to better understanding the causal relationship between ICTs and service exports for each set of countries and for a global panel. It also suggests some practical recommendations, especially for developing economies.

Several countries have achieved remarkable success in profiting from the new opportunities for service trade offered by ICT (Tchamyou et al. 2019). Specific services for industries, such as banking, insurance, and telecommunications account for nearly two-thirds of all potential ICT-enabled services market. Services that act as an inputs for industries (e.g. finance, administration, transport, marketing, etc.) count for one-third of the service market. For developing countries, the share of service trade has grown from 29\% in 2005 to $38 \%$ in 2015 (OECD-WTO, 2017). India has become the world's most important sourcing destination, accounting for approximately $60 \%$ of the USD 173-178 billion market in 2016-2017 (UNCTAD, 2017). Hence, it epitomizes the model of an ambitious developing country that has developed a solid export capacity in IT services. Success has also been achieved in Jordan, the 
Philippines, and Senegal, which have made considerable efforts to supply services across borders (Balchin et al. 2016).

\section{Related Literature}

Several papers examined links between internet penetration and service trade at the international level. Freund and Weinhold (2002) empirically investigated the relationship between ICT and service trade using a panel sample covering 31 countries and 14 industries between 1995 and 1996. When including internet penetration in the estimation, they found a significant effect related to service trade, whereby an increase in internet penetration by $10 \%$ can increase export growth by $1.7 \%$, and import growth by $1.1 \%$. Choi (2010) examined the role of ICT on the development of services trade across countries. Using panel data for 151 countries over the period 1990-2006, he found a significant correlation between the development of internet adoption and the total service trade. In terms of results, he showed that an increase of $10 \%$ in the internet penetration is able to significantly boost service trade. It should be noted that this finding is different compared to others.

Liu and Nath (2013) examined the links relating internet adoption to service trade in emerging markets (EMEs) over the period 1995-2010. Using fixed effects models, they showed that internet penetration positively affects trade in EMEs. This can be partly explained by the use of internet technology (among other factors). Therefore, public policy seeking to enhance ICT should improve trade in EMEs. Sahoo et al. (2013) studied the main determinants of India's service exports, analyzing factors that influence the performance of traditional and modern service exports over the past three decades. They used explanatory variables as determinants of India's services to determine positive impacts of institutions, FDI, and financial development on modern export services. In terms of public policy, they recommended that India further develop its supply-side factors in order to increase service exports.

Covaci and Moldovan (2015) examined some factors which can influence both service exports and a selection of some specified services in Lithuania between 2003 and 2012. They found that destination GDP and a common spoken language had positive impacts on international trade of services. In addition, it appears that time zone change, localization, and skilled labour had different effects in relation to the seven services considered. Also, the significance of the geographical distance between countries depended on the type of service; with the exception of transport services, the distance was not significant for the other specified services. The same empirical method was developed by Pham and Vũ (2016) in relation to Vietnam and different European economies between the years of 2002 and 2011. They illustrated the importance of per capita GDP, population, and real exchange rate between Vietnam and its commercial partners as the main determinants of international service exports.

Nasir and Kalirajan (2016) underlined the importance of exported services for Asian countries (e.g. computer, information, business, and telecommunications). They showed that the export performances for these countries are less efficient compared with developed countries. Also, they underlined the importance of qualified labour and internet in emerging countries to improve the trade of modern services. However, ASEAN economies with strong manufacturing sectors are perform less well in terms of service exports. Despite its strong reputation in terms of ICT-enabled services, even India has not yet reached its export potential in modern services.

Other papers identified the main determinants of using the internet (Lera-López et al. 2011), frequently explained using the diffusion theory theoretical framework (Rogers, 2003), whereby an increasing number of internet users increases the probability for non-users to adopt internet usage. Internet adoption is generally faster in urban areas than in rural ones, mainly due to the greater availability of supporting infrastructure and more need for internet access (Gaspar and Glaeser, 1998). Consequently, internet use increases as population and density rise, thereby leading to a decrease in the cost of internet access (Karshenas and Stoneman, 1995). Internet use itself is explained by some socio-economic factors such as education level, wage, familiar composition, occupation, and geography (urban or rural). Several authors found empirical evidence for the association between the quality of education, higher levels of income, and internet adoption (Goldfarb and Prince, 2008; Al-Hammadany and Heshmati, 2011). Socio-economically privileged people (i.e. the wealthy and well-educated) are more likely to be able to adopt and benefit from technological innovations such as the internet. Moreover, internet adoption allows people to profit from additional advantages and opportunities, depending to their education and income levels. Put simply, rich people may gain more economic benefits from the internet than poor people (Mills and Whitacre, 2003).

In addition to demand factors, the literature also noted the importance of supply factors in internet adoption. Despite the development of internet access, these factors seem to be particularly relevant. For example, if the internet penetration cost decreases by 50\%, then computer hosts may increase by $25 \%$ in 23 OECD countries (Kiiski and Pohjola, 2002). Internet cost depends on local competition among internet service providers in addition to the existence of ICT infrastructure (Grubesic, 2008). 


\section{Methods}

\subsection{Data}

To investigate the causal relationship between internet adoption and service exports, we used an unbalanced panel (Note 1) data collected from the World Bank over the period 2000-2017. The selection of dataset and time frame is conditioned by the availability of information.

This empirical investigation concerns a sample of 116 countries; there are few previous studies that cover a large sample of countries. In addition, we divided our global dataset into two sub-panels to consider specific characteristics. Considering the development level for each sub-panel allows us to obtain more homogenous analysis and to avoid fallacious results. Moreover, we confirm that the developed countries are fully able to profit from the efficient access to the internet to enhance their service exports, while developing countries are the most vulnerable, despite their more pressing need to improve their capacity for service trade. For the developed sub-panel, the role of the internet is very significant and important for service exports flows, but this importance decreases for developing countries. For these reasons, we examine the causal links relating the internet adoption to the service exports. Table 1 shows the variable definitions used for this study and the related data sources. Table 2 describes the used variables. Table 3 indicates the correlation matrix. The existence of significant correlation between SEREXP and ICT evinces that a simultaneous estimation may be taking place, thus we must take into account any eventual endogeneity issue in the estimation. In general, we note that all explanatory variables are positively correlated.

Table 1. Variable definitions

\begin{tabular}{lll}
\hline Variables & Description & Sources \\
\hline SEREXP & Service exports (BoP, current USD) & WDI (2019) \\
\hline ICT & Individuals using the internet (\% of population) & WDI (2019) \\
\hline SEREMP & Employment in service (\% of total employment) & WDI (2019) \\
\hline INDEMP & Employment in industry (\% of total employment) & WDI (2019) \\
\hline GDP & Per capita GDP (constant, 2010 USD) & WDI (2019) \\
\hline POP & Population (total) & WDI (2019) \\
TO & Trade openness (\% of imports and exports of GDP) & WDI (2019) \\
FDI & FDI, net inflows (\% of GDP) & WDI (2019) \\
\hline URB & Urban population (\% of total) & WDI (2019) \\
\hline
\end{tabular}

\subsection{Estimation Specification}

In order to investigate the causal links between service exports and ICT, we adopt a similar modelling approach as used in several papers focused on air transport services and economic development (e.g. Green, 2007; Bel and Fageda, 2008; Percoco, 2010). Indeed, transport services, like other specialized intermediate inputs (e.g. telecommunications, tourism, marketing, finance, etc.), could be traded abroad by profiting from the development of ICT (Markusen, 1989; Markusen and Strand, 2008). In this study, we estimate dynamic panel models using the 2-step GMM methodology. This strategy is chosen for five principal reasons (Asongu, 2019): (i) the selected countries $(n=116)$ exceeds the number of periods in the study; (ii) the dependent variable is unchangeable, since its first lag variable is larger than 0.8 ; (iii) the specification considers endogeneity issues in using the instrumentation and time-invariant absent variables; (iv) the system estimators amends latent biases in the difference estimator; and (v) since our empirical strategy uses panel data, differences inter-groups are considered in estimations.

We use the Arrelano and Bover (1995) methodology developed by Roodman (2009). The choice of this procedure is due to its capability to mitigate the proliferation of instruments and consider the cross-sectional dependence (Love and Zicchino, 2006). The standard GMM estimation procedure is described below. It should be noted that the equations of the system are specified when we get at least one significant independent variable in eq. (1) and (2). The system of equations is presented as follows.

$$
\begin{aligned}
\ln S E R E X P_{i, t} & =\alpha_{0} \ln S E R E X P_{i, t-1}+\psi \ln I C T_{i, t}+\delta X_{i, t}+\mu_{i, t}+\varepsilon_{i, t} \\
\ln I C T_{i, t} & =\beta_{0} \ln I C T_{i, t-1}+\phi \ln S E R E X P_{i, t}+\delta X_{i, t}+\mu_{i, t}+\varepsilon_{i, t}
\end{aligned}
$$


where SEREXP and ICT represent respectively the service exports and the internet adoption of country $i$ at time $t$. $X$ indicates the vector of explanatory variables used in each equation to model service exports (internet penetration, service employment, industrial employment, per capita GDP, and trade openness), and internet adoption (service exports, level of urbanization, population, and FDI). $\mu_{i, t}$ captures the unobservable individual specific effect. $\varepsilon_{i, t}$ represents the error term, which varies across countries and over time.

We also report the Arellano and Bond (1991) test in which the null hypothesis (H0) shows that the differenced errors are auto-correlated if the regression errors are independent and identically distributed. The Hansen $J$-test results confirm the acceptance of the null hypothesis ( $\mathrm{H} 0)$, which means that the instruments are appropriate. However, the rejection of the null hypothesis (H0) should indicate that the choice of instruments is not consistent. Similarly, AR (2) tests illustrate the absence of autocorrelation at levels of significance. Consequently, we can conclude that the dynamic panel model is a good empirical specification which enables us to better investigate the linkages between service exports and internet adoption.

Table 2. Descriptive statistics for the period 2000-2017

\begin{tabular}{llllll}
\hline Variable & Obs. & Mean & Std. Dev. & Min & Max \\
\hline SEREXP & 1.972 & $2.53 \mathrm{E}+09$ & $7.41 \mathrm{E}+09$ & 51000 & $7.92 \mathrm{E}+10$ \\
\hline SEREMP & 2.070 & 54.474 & 17.443 & 13.385 & 87.848 \\
\hline INDEMP & 2.070 & 21.355 & 7.783 & 2.902 & 59.576 \\
\hline ICT & 2.067 & 34.278 & 29.472 & .0152 & 98.26 \\
\hline GDP & 2.085 & 15821.26 & 20501.47 & 194.873 & 111968.4 \\
\hline TO & 2.062 & 88.108 & 53.75406 & 19.100 & 441.603 \\
\hline POP & 2.088 & $5.21 \mathrm{e}+07$ & $1.69 \mathrm{e}+08$ & 81131 & $1.39 \mathrm{e}+09$ \\
\hline FDI & 2.079 & 5.569 & 18.545 & -58.322 & 451.715 \\
\hline URB & 2.088 & 58.872 & 22.865 & 13.397 & 100 \\
\hline
\end{tabular}

a: The number of observations is given by $\sum_{i=1}^{116} T_{i}=2088$

Table 3. Correlation matrix

\begin{tabular}{|c|c|c|c|c|c|c|c|c|c|}
\hline & SEREXP & SEREMP & INDEMP & ICT & GDP & TO & POP & FDI & URB \\
\hline SEREXP & 1.000 & & & & & & & & \\
\hline \multirow[t]{2}{*}{ SEREMP } & $0.198 * * *$ & 1.000 & & & & & & & \\
\hline & $(0.0000)$ & & & & & & & & \\
\hline \multirow{2}{*}{ INDEMP } & $0.061 * * *$ & $0.452^{*}$ & 1.000 & & & & & & \\
\hline & $(0.0029)$ & $(0.0000)$ & & & & & & & \\
\hline \multirow[t]{2}{*}{ ICT } & $0.310 * * *$ & $0.694 * * *$ & $0.354 * * *$ & 1.000 & & & & & \\
\hline & $(0.0000)$ & $(0.0000)$ & $(0.0000)$ & & & & & & \\
\hline \multirow[t]{2}{*}{ GDP } & $0.338^{* * *}$ & $0.664 * * *$ & $0.257 * * *$ & $0.713^{* * *}$ & 1.000 & & & & \\
\hline & $(0.0000)$ & $(0.0000)$ & $(0.0000)$ & $(0.0000)$ & & & & & \\
\hline \multirow[t]{2}{*}{ TO } & -0.006 & $0.302 * * *$ & $0.180^{* * * *}$ & $0.264 * * *$ & $0.304^{* * *}$ & 1.000 & & & \\
\hline & $(0.7927)$ & $(0.0000)$ & $(0.0000)$ & $(0.0000)$ & $(0.0000)$ & & & & \\
\hline
\end{tabular}




\begin{tabular}{lllllllllll}
\hline POP & $0.498^{* * *}$ & $-0.180^{* * *}$ & $0.036^{* *}$ & $-0.068^{* * * *}$ & -0.085 & $-0.208^{* *}$ & 1.000 & & \\
& $(0.0000)$ & $(0.0001)$ & $(0.0977)$ & $(0.0017)$ & $(0.0001)$ & $*$ & & & \\
& & & & & & $(0.0000)$ & & & \\
\hline FDI & 0.006 & $0.120^{* * *}$ & 0.162 & $0.089^{* * *}$ & $0.113^{* * *}$ & $0.334^{* * *}$ & $-0.050^{* *}$ & 1.000 & \\
& $(0.7849)$ & $(0.0000)$ & $(0.4622)$ & $(0.0000)$ & $(0.0000)$ & $(0.0000)$ & $(0.0216)$ & & \\
\hline URB & $0.157^{* * *}$ & $0.715^{* * *}$ & $0.476^{* * *}$ & $0.653^{* * *}$ & $0.637^{* * *}$ & $0.226^{* * *}$ & $-0.102^{* * *}$ & $0.115^{* * *}$ & 1.000 \\
& $(0.0000)$ & $(0.0000)$ & $(0.0000)$ & $(0.0000)$ & $(0.0000)$ & $(0.0000)$ & $(0.0000)$ & $(0.0000)$ & \\
\hline
\end{tabular}

The estimated p-values are within parentheses

*** Significant at $1 \%$. ** Significant at $5 \%$. $*$ Significant at $10 \%$

\section{Results and Discussions}

To explore the causality between the service exports and internet adoption, the 2-Step GMM estimators are used. Two different specifications are identified for each panel to estimate the equation system (1-2). The empirical findings for total panel are reported in Table 4.

Model (1) illustrates a significant relationship between the internet adoption (ICT) and service exports (SEREXP). The coefficient of 0.127 indicates that if the internet penetration increases by $10 \%$ then the service exports grows by $1.27 \%$. The results are similar to those of Freund and Weinhold (2002), who found a positive link between ICT and service exports. If internet penetration increases by $10 \%$, then service exports increase by $1.7 \%$, and service imports by $1.1 \%$. Also, the results show the positive effect of trade openness $(T O)$ on service exports. The coefficient of 0.639 allows us to confirm that the service exports may increase by $6.39 \%$ if the trade grows by $10 \%$.

Model (2) shows that population $(P O P$ ) positively affects internet adoption. In terms of elasticities, a $10 \%$ increase in population involves around a $3.64 \%$ increase in the internet penetration. These findings also demonstrate a significant effect of urbanization (URB) on internet adoption. A magnitude of 0.407 indicates that when the urban population increases by $10 \%$, internet penetration improves by $4.07 \%$. When an urban area is larger, the probability of more internet users increases (Lera-López et al. 2011). This strong relationship is also found by Al-Hammadany and Heshmati (2011). For the global panel, it should be noted that service exports do not affect significantly internet adoption. This result confirms the existence of a single one-way causality going from internet adoption to service exports.

Table 4. Results for the total panel

\begin{tabular}{lll}
\hline Variables & Model 1 & Model 2 \\
\cline { 2 - 3 } & Ln SEREXP & Ln ICT \\
\hline Ln SEREXP $(-1)$ & $0.637^{* * *}(0.000)$ & $0.824^{* * *}(0.000)$ \\
\hline Ln ICT $(-1)$ & & $0.024(0.558)$ \\
\hline Ln SEREXP & & \\
\hline Ln SEREMP & $0.137(0.842)$ & $-0.049(0.827)$ \\
\hline Ln INDEMP & $-0.209(0.543)$ & \\
\hline Ln ICT & $0.127^{* *}(0.022)$ & $0.656^{* * *}(0.002)$ \\
\hline Ln GDP & $0.318(0.408)$ & $0.00008(0.558)$ \\
\hline Ln TO & $0.639^{* * *}(0.001)$ & $0.485^{* *}(0.016)$ \\
\hline Ln POP & & $91.15(0.332)$ \\
\hline FDI & &
\end{tabular}




\begin{tabular}{lll}
\hline $\mathrm{AR}(2)$ test $(\mathrm{p}$-value) & $0.47(0.639)$ & $0.47(0.640)$ \\
\hline Number of instruments & 112 & 92 \\
\hline Number of countries & 115 & 116 \\
\hline Observations & 1680 & 1723 \\
\hline
\end{tabular}

The estimated p-values in brackets

*** Significant at $1 \%$.** Significant at $5 \%$. Significant at $10 \%$

The results for developed countries are shown in Table 5. Model (1) shows that the internet adoption positively influences service exports. Countries with greater internet penetration also have higher service exports growth. We found that if internet adoption increases by $10 \%$ then the service exports commensurately increase by $4.86 \%$. This result confirms the findings of Choi (2010). The pioneering work by Freund and Weinhold (2002) anticipated an eventual dynamic relationship between the internet penetration and US service exports in the long run. A $10 \%$ increase in the internet penetration may improve US exports by $4 \%$. The results illustrate the positive impact of GDP per capita in developed countries. In terms of elasticities, if the per capita GDP increases by $10 \%$ then the service exports increase by $17.56 \%$.

Model (2) indicates that service exports (SEREXP) positively affect internet penetration. We found that internet adoption improves by $0.24 \%$ when the service exports increase by $10 \%$. This result is important because it confirms the existence of bi-directional links relating SEREXP to ICT, thereby affirming the expectations of Freund and Weinhold (2002). For instance, the development of service exports may encourage companies to use ICT in order to improve that trade, and efficient internet access leads companies to employ the internet in service exports activities. The coefficient of population shows a positive and significant sign: a coefficient of 0.263 indicates that a $10 \%$ increase in population implies an increase in the internet penetration by $2.63 \%$.

Table 5. Results for developed countries

\begin{tabular}{lll}
\hline \multirow{2}{*}{ Variables } & Model 1 & Model 2 \\
\cline { 2 - 3 } & Ln SEREXP & Ln ICT \\
\hline Ln SEREXP $(-1)$ & $0.306^{* *}(0.022)$ & $0.262^{* * *}(0.000)$ \\
\hline Ln ICT $(-1)$ & & $0.024^{*}(0.088)$ \\
\hline Ln SEREXP & & \\
\hline Ln SEREMP & $0.950(0.764)$ & \\
\hline Ln INDEMP & $-1.035(0.288)$ & \\
\hline Ln ICT & $0.486^{* *}(0.046)$ & $0.263^{*}(0.056)$ \\
\hline Ln GDP & $1.756^{* * *}(0.001)$ & $0.0001(0.795)$ \\
\hline Ln TO & $0.149(0.537)$ & $0.270(0.468)$ \\
\hline Ln POP & & $26.08(0.514)$ \\
\hline FDI & & $-0.33(0.739)$ \\
\hline Ln URB & & 32 \\
\hline Hansen J-test (p-value) & $29.33(0.250)$ & 34 \\
\hline AR(2) test (p-value) & $-1.14(0.253)$ & 495 \\
\hline Number of instruments & 31 & \\
\hline Number of countries & 34 & \\
\hline Observations & 487 & \\
\hline The estimated p-values in brackets & Significant at 10\% \\
$* * *$ Significant at 1\%. $* *$ Significant at 5\%. & \\
\hline
\end{tabular}


Table 6 shows the results related to developing countries. Model (1) shows that the internet adoption positively and significantly influences the service exports. The magnitude of 0.189 indicates a $1.89 \%$ increase in service exports when internet adoption increases by $10 \%$. Despite the significant effect of internet adoption on service exports, it is considered less efficient compared with its impact in developed countries. These results confirm the findings of Nasir and Kalirajan (2016) when comparing emerging economies with developed ones. Also, the results indicate that trade openness positively and significantly influences service exports. The coefficient of 0.772 indicates that if the trade increases by $10 \%$, then it leads to $7.72 \%$ increase in the service exports.

Model (2) shows that the GDP per capita positively affects internet adoption. The coefficient of 0.693 notes an augmentation by $6.93 \%$ in internet penetration when per capita GDP increases by $10 \%$. This result is in accordance with the findings of Pham and Vũ (2016). The degree of urbanization plays an important role in internet penetration. A coefficient of 0.414 indicates a $4.14 \%$ increase in internet adoption when the urban population increases by $10 \%$. Finally, it also appears that population positively and significantly affects internet access in developing countries. The magnitude of 0.984 implies that a $10 \%$ increase in the population involves around a $9.84 \%$ increase in internet adoption. However, the impact is positive and statistically insignificant for FDI.

Table 6. Results for developing countries

\begin{tabular}{lll}
\hline \multirow{2}{*}{ Variables } & Model 1 & Model 2 \\
\cline { 2 - 3 } & Ln SEREXP & Ln ICT \\
\hline Ln SEREXP $(-1)$ & $0.506^{* * *}(0.000)$ & $0.724^{* * *}(0.000)$ \\
\hline Ln ICT $(-1)$ & & $0.020(0.622)$ \\
\hline Ln SEREXP & & \\
\hline Ln SEREMP & $1.216(0.607)$ & \\
\hline Ln INDEMP & $-1.050(0.147)$ & $0.693^{* *}(0.032)$ \\
\hline Ln ICT & $0.189^{* *}(0.031)$ & $0.984^{* * *}(0.000)$ \\
\hline Ln GDP & $0.016(0.978)$ & $0.003(0.608)$ \\
\hline Ln TO & $0.772^{* *}(0.031)$ & $0.414^{*}(0.063)$ \\
\hline Ln POP & & $59.69(0.414)$ \\
\hline FDI & & $0.55(0.581)$ \\
\hline Ln URB & & 64 \\
\hline Hansen J-test (p-value) & $58.37(0.318)$ & 68 \\
\hline AR(2) test (p-value) & $0.41(0.682)$ & 1021 \\
\hline Number of instruments & 60 & 68 \\
\hline Number of countries & 1003 & \\
\hline Observations & & \\
\hline
\end{tabular}

The estimated p-values in brackets

*** Significant at $1 \%$.** Significant at $5 \%$ * Significant at $10 \%$

\section{Conclusion and Implications}

This article examined the causal relationship between service exports and internet adoption. Taking into account the development level of countries, we divided our sample in two-subpanels, developing and developed countries, using the GMM procedure. The data collected came principally from the World Bank (WDI, 2019). The findings illustrated the positive impact of internet adoption on service exports for all countries. This result is in accordance with the findings of Choi (2010) and Liu and Nath (2013). Moreover, this confirms the expectations of Freund and Weinhold (2002), who predicted that if the dynamic relationship between internet penetration and US service exports continued in the long run, then a $10 \%$ improvement in internet penetration would increase US service exports by $4 \%$. 
For developing countries, it is worth noting that internet adoption is less efficient compared with developed countries, despite its positive impact on service exports.

Another finding is the existence of a causal relationship between internet adoption and service exports. For developed countries, bi-directional causality demonstrably related internet adoption to service exports. This causal result confirms the expectations of Freund and Weinhold (2002), who expected that this causality probably runs in both directions for the US. Indeed, increasing service trade may encourage companies to adopt the new technologies in order to improve that trade, and better internet access allows companies to adopt internet for service trade. For the global panel and the developing countries we found results confirming the positive impact of internet adoption on service exports, but conversely the impact was very weak and insignificant for those economies.

The findings imply some important policy implications, especially for developing countries. In this study, we realized that governments should adopt policy options to increase internet penetration and adoption, in order to consequently improve their service economy. First, they have to invest more in the extension of internet networks, not only in urban zones but also in the rural zones, whose degree of urbanization is lower and who are generally disadvantaged in terms of access to goods and services; such communities stand to gain most from internet adoption. Moreover, efficient internet access for both businesses and educated people is able to encourage the exportation of specialized services without the use of transportation modes. Consequently, developing countries should invest more in education and ICT infrastructures than in transportation networks. This policy option would be profitable for developing countries, especially for landlocked ones, as it contributes to attract FDI.

In terms of limitations and future research, we will attempt to improve this study by considering a selection of some specified services (e.g. finance, insurance, telecommunication, business, transport, and travel, etc.), which can be traded abroad using ICTs. We also aim to utilize other indicators for ICTs because in this study we used a simple indicator that cannot necessarily reflect the quality of internet (e.g. high-speed connections, 5G networks, public expenditure, etc.) and its supported infrastructures. The integration of other factors would be useful to better understand the causal relationship between ICTs and trade in services.

\section{References}

AL-Hammadany, F., \& Heshmati, A. (2011). Determinants of internet use in Iraq. International Journal of Communication, 5, 1967-1989.

Arellano, M., \& Bond, S. (1991). Some tests of specification for panel data: Monte Carlo evidence and an application to employment equations. Review of Economic Studies, 58(2), 277-297. https://doi.org/10.2307/2297968

Arellano, M., \& Bover, O. (1995). Another look at the instrumental variable estimation of error-components models. Journal of Econometrics, 68(1), 29-51. https://doi.org/10.1016/0304-4076(94)01642-D

Asongu, S. A., Le Roux, S., \& Biekpe, N. (2018). Enhancing ICT for environmental sustainability in sub-Saharan Africa. Technological Forecasting and Social Change, 127, 209-216. https://doi.org/10.1016/j.techfore.2017.09.022

Asongu, S. A., Nwachukwu, J. C., \& Pyke, C. (2019). The comparative economics of ICT, environmental degradation and inclusive human development in Sub-Saharan Africa. Social Indicators Research, 143(3), 1271-1297. https://doi.org/10.1007/s11205-018-2009-x

Balchin, N., Hoekman, B., Martin, H., Mendez-Parra, M., Papadavid, P., Primack, D., \& Willem te Velde, D. (2016). Trade in services and economic transformation. Overseas Development Institute, London, UK.

Baltagi, B. H., \& Chang, Y. J. (2000). Simultaneous equations with incomplete panels. Economic Theory, 16(2), 269-279. https://doi.org/10.1017/S0266466600162073

Bel, G., \& Fageda, X. (2008). Getting there fast: globalization, intercontinental flights and location of headquarters. Journal of Economic Geography, 8(4), 471-495. https://doi.org/10.1093/jeg/lbn017

Boateng, A., Asongu, S. A., Akamavi, R., \& Tchamyou, V. S. (2016). Information asymmetry and market power in the African banking industry. African Governance and Development Institute, Working Paper No. 16/032, Yaoundé. https://doi.org/10.2139/ssrn.2834710

Chatti, W. (2020). Information and communication technologies, road freight transport, and environmental sustainability. Environmental Economics, 11(1), 124-132. https://doi.org/10.21511/ee.11(1).2020.11 
Chatti, W., Ben Soltane, B., \& Abalala, T. (2019). Impacts of public transport policy on city size and welfare. Networks and Spatial Economics, 19(4), 1097-1122. https://doi.org/10.1007/s11067-019-09451-y

Choi, C. (2010). The effect of the internet on services trade. Economics Letters, 109(2), 102-104. https://doi.org/10.1016/j.econlet.2010.08.005

Covaci, G., \& Moldovan, S. (2015). Determinants of service exports of Lithuania: a gravity model approach. SSE Riga Student Research Papers, 1, 166.

Fink, C., Mattoo, A., \& Neagu, I. C. (2005). Assessing the impact of communication costs on international trade. Review of International Economics, 67(2), 428-445. https://doi.org/10.1016/j.jinteco.2004.09.006

Freund, C., \& Weinhold, D. (2002). The internet and international trade in services. American Economic Review, 92(2), 236-240. https://doi.org/10.1257/000282802320189320

Gaspar, J., \& Glaeser, E. (1998). Information technology and the future of cities. Journal of Urban Economics, 43(1), 136-156. https://doi.org/10.1006/juec.1996.2031

Goldfarb, A., \& Prince, J. (2008). Internet adoption and usage patterns are different: Implications for the digital divide. Information Economics and Policy, 20(1), 2-15. https://doi.org/10.1016/j.infoecopol.2007.05.001

Green, R. K. (2007). Airports and economic development. Real Estate Economics, 35(1), 91-112. https://doi.org/10.1111/j.1540-6229.2007.00183.x

Grossman, G. M., \& Rossi-Hansberg, E. (2008). Trade in tasks: a simple theory of off shoring. American Economic Review, 98(5), 1978-1997. https://doi.org/10.1257/aer.98.5.1978

Grubesic, T. H. (2008). ZIP Codes and spatial analysis: problems and prospects. Socio-Economic Planning Sciences, 42(2), 129-149. https://doi.org/10.1016/j.seps.2006.09.001

Human Development Reports (HDR). (2019). Global Human Development Indicators. Retrieved October 5, 2019, from http://hdr.undp.org/en/countries

Karshenas, M., \& Stoneman, P. (1995). Technological diffusion. In P. Stoneman (Ed.), Handbook of the economics of innovation and technological change (pp. 265-297). Oxford: Blackwell.

Kiiski, S., \& Pohjola, M. (2002). Cross-country diffusion of the internet. Information Economics and Policy, 14(2), 297-310. https://doi.org/10.1016/S0167-6245(01)00071-3

Lera-López, F., Billon, M., \& Gil, M. (2011). Determinants of internet use in Spain. Economics of Innovation and New Technology, 20(2), 127-152. https://doi.org/10.1080/10438590903378017

Liu, L., \& Nath, H. K. (2013). Information and Communications Technology and trade in emerging market economies. Emerging Markets Finance and Trade, 49(6), 67-87. https://doi.org/10.2753/REE1540-496X490605

Love, I., \& Zicchino, L. (2006). Financial development and dynamic investment behaviour: evidence from panel VAR. Quarterly Review of Economics and Finance, 46(2), 190-210. https://doi.org/10.1016/j.qref.2005.11.007

Maddala, G. S., \& Wu, S. (1999). A Comparative study of unit root tests with panel data and a new Simple Test. Oxford Bulletin of Economics and Statistics, 61(S1), 631-652. https://doi.org/10.1111/1468-0084.0610s1631

Markusen, J. (1989). Trade in producer services and in other specialized intermediate inputs. American Economic Review, 79(1), 85-95.

Markusen, J. R., \& Strand, B. (2008). Off shoring of business services in small open Economies: toward a general-equilibrium modelling approach. Journal of Industry, Competition and Trade, 8(3-4), 231-246.

Maurseth, P. B., \& Verspagen, B. (1999). Knowledge spillovers in Europe and its consequences for systems of innovations. Edward Elgar, London.

Mills, B. F., \& Whitacre, B. E. (2003). Understanding the non-metropolitan-metropolitan digital divide. Growth and Change, 34(2), 219-243. https://doi.org/10.1111/1468-2257.00215

Nasir, S., \& Kalirajan, K. (2016). Modern service exports performances among emerging and developed Asian economies. Asian Development Review, 33(1), 1-27. https://doi.org/10.1162/ADEV_a_00059

Organisation for Economic Co-operation and Development. (2008). The contribution of services to development and the role of trade liberalisation and regulation. ODI Briefing Notes. In Global forum on international investment. DFID, UK. 
Organisation for Economic Co-operation and Development-World Trade Organization (OECD-WTO). (2017). Aid for Trade Monitoring Exercise 2017. Retrieved October 10, 2019, from www.oecd.org/aidfortrade/countryprofiles/

Percoco, M. (2010). Airport activity and local development: Evidence from Italy. Urban Studies, 47(11), 2427-2443.

Pham, N. V., \& Vũ, H. T. (2016). Analysing the determinants of service trade flows between Vietnam and the European Union: a gravity model approach. VNU Journal of Science: Economics and Business, 30, 51-64.

Phillips, P. C. B., \& Perron, P. (1998). Testing for unit roots in time series regression. Biometrika, 75, 335-346.

Riou, S. (2003). How growth and location are sensitive to transport and telecommunications infrastructures. Louvain Economic Review, 69(3), 241-265. https://doi.org/10.3917/rel.693.0241

Rogers, E. (2003). Diffusion of innovations. New York.

Roodman, D. (2009). How to do xtabond2: An introduction to difference and system GMM in Stata. The Stata Journal, 9(1), 86-136. https://doi.org/10.1177/1536867X0900900106

Sahoo, P., Kumar-Dash, R., \& Prasad-Mishra, P. (2013). Determinants of India's service exports. In Reviving growth in India. Cambridge University Press, India.

Tang, L. (2006). Communication costs and trade of differentiated goods. Review of International Economics, 14(1), 54-68. https://doi.org/10.1111/j.1467-9396.2006.00560.x

Tchamyou, V. S., Erreygers, G., \& Cassimon, D. (2019). Inequality, ICT and financial access in Africa. Technological Forecasting and Social Change, 139, 169-184. https://doi.org/10.1016/j.techfore.2018.11.004

United Nations Conference on trade and development, UNCTAD. (2017). International Trade in Services. UNCTAD Handbook of Statistics, Geneva, Switzerland.

World Bank, World Development Indicators (WDI). (2019). Retrieved October 5, 2019, from http://datatopic.worldbank.org/world-development-indica\&tors/

World Bank. (2016). Digital Dividends. World Development Report, Washington, DC, USA.

World Trade Organization, WTO. (2016). International trade statistics. Special Focus: World Trade and the WTO: 1995-2014.

\section{Note}

Note 1. Developed: Australia, Austria, Belgium, Canada, Croatia, Cyprus, Czech Republic, Denmark, Estonia, Finland, France, Germany, Greece, Hungary, Hungary, Iceland, Ireland, Israel, Italy, Japan, Luxembourg, Malta, Netherlands, New Zeeland, Norway, Poland, Portugal, Singapore, Slovenia, South Korea, Spain, Switzerland, United Kingdom, and United States.

Developing: Albania, Algeria, Armenia, Azerbaijan, Bahrain, Bangladesh, Belarus, Belize, Benin, Bolivia, Bosnia and Herzegovina, Botswana, Bulgaria, Burkina Faso, Cabo Verde, Cambodia, Cameroon, Chile, Colombia, Costa Rica, Cote d'Ivoire, Dominican Republic, Egypt, El Salvador, Eswatini, Ethiopia, Guatemala, Guinea, Guyana, Haiti, Honduras, Indonesia, Jamaica, Kenya, Kuwait, Kyrgyz Republic, Lebanon, Lesotho, Libya, Madagascar, Malawi, Mauritius, Moldova, Morocco, Namibia, Nepal, Nicaragua, Niger, Nigeria, North Macedonia, Oman, Pakistan, Panama, Paraguay, Peru, Philippines, Qatar, Saudi Arabia, Senegal, Seychelles, Solomon Islands, Sri Lanka, St. Lucia, Sudan, Tanzania, Thailand, Togo, Tunisia, Uganda, Venezuela, and Zambia.

Emerging: Argentina, Brazil, China, India, Malaysia, Mexico, Romania, Russia, South Africa, Turkey, and Ukraine.

\section{Copyrights}

Copyright for this article is retained by the author(s), with first publication rights granted to the journal.

This is an open-access article distributed under the terms and conditions of the Creative Commons Attribution license (http://creativecommons.org/licenses/by/4.0/). 